\title{
Social Solidarity Of Students In State SMA Kupang City
}

\author{
Fespy 0. Toineno, S.Pd \\ History Education Postgraduate Program, \\ Sebelas Maret State University Surakarta \\ Prof. Dr. Muhammad Akhyar, M.Pd \\ History Education Postgraduate Program, \\ Sebelas Maret State University Surakarta \\ Prof. Dr. Nunuk Suryani, M.Pd \\ History Education Postgraduate Program, \\ Sebelas Maret State University Surakarta
}

\begin{abstract}
Social solidarity is the togetherness of individuals or groups that arise from moral feelings and shared beliefs that are reinforced by shared emotional experiences. Durkheim in Maliki said, there are two social solidarity namely mechanical solidarity and organic solidarity. Mechanical solidarity is an individual's awareness in carrying out social life based on the foundation of identity among its members. Whereas organic solidarity is an awareness developed on the basis of social cohesion through different solidarity models within the class of its members. This research uses descriptive qualitative method, research location in the city of Kupang. Data collection is done through library research, observation, in-depth interviews, and documentation techniques. The informants in this study were students of the State Senior High School in Kupang. Data analysis techniques used in this study were by means of data collection, data reduction, data presentation and drawing conclusions. The results showed that organic social solidarity was quite prominent in students. In the process of student social interaction, organic solidarity is more prominent. This is seen through one of the student activities in the learning process such as the division of study groups. The behavior of choosing friends according to liking, emotional closeness is very prominent. While the division of student roles is going well, but individuality or competition in groups and competition with other groups of students is inevitable.
\end{abstract}

Keywords: Solidarity, Social, Students, Schools

\section{Background}

PRELIMINARY

Social solidarity is a daily activity that shows a human social interaction in daily life. In essence, humans are social beings who need each other in living life in a social environment. For the creation of a shared life between humans it is very important for social interaction between one another (Soekanto, 2007: 54).

A person as an individual in the social environment can change the surrounding community, Proven that humans can spark a new idea for a gradual change which is known as a social process or the process of forming a society. Changes that occur in an individual can be categorized as intentional or unintentional social changes. Solidarity at this time has begun to fade. Disunity among human beings will increase if there is no solidarity that starts from within or is implanted as early as possible. The feeling of solidarity, the same fate in arms, faithfulness, 
the nature of a sense of solidarity in various kinds of circles, is very minimal and many are forgotten for self-satisfaction.

Solidarity is very important because it greatly influences social change, which includes the attitude of everyone and the conditions of an environment dominated by differences. This difference causes social solidarity to disappear from generation to generation. Creating an organized social condition is the goal of social solidarity. The differences that surround us are not to be laughed at or exiled, but that is where the important role of solidarity is to equalize and unite feelings of tolerance. The important role of solidarity can be measured by its success if solidarity can create unity and equality of struggle in society.

The things that happen if there is no solidarity around us are the emergence of stereotypes, prejudices and primodialism, maintaining what he thinks is best, not wanting to open up and berate other groups, and brawls between groups. This is an example that could potentially occur if it is not based on solidarity. The young generation as the successor to the ideals of the nation that should have a solider personality in the form of empathy, mobility, participation to increase solidarity in the social life of the community.

Therefore solidarity should be applied as early as possible to the next generation of the nation. One solution is that solidarity must be applied or addressed in the school environment. Given the importance of solidarity in the name of difference can enrich relations, culture and unity, solidarity must be cultivated and maintained. The way to build solidarity from the simplest is respecting people who are worshiping, congratulating people who celebrate holidays, and not picking out friends. Mutual respect for people who are not of my ethnicity, different beliefs and status, is also very emphasized in terms of solidarity so that as a nation that is rich in diversity can be maintained from the present to the future.

\section{FORMULATION OF THE PROBLEM}

Based on the background description above, the formulation of the problem in this study is as follows:

1. What is the form of social solidarity among high school students in the city of Kupang?

2. What factors form the basis of social solidarity among high school students in the city of Kupang?

\section{RESEARCH PURPOSES}

The objectives of this research are:

1. To describe how the form of social solidarity among high school students over the city of Kupang.

2. To find out the factors that form the basis of social solidarity among high school students in the city of Kupang.

The uses of this research are:

\section{USE OF RESEARCH}

1. Theoretical use, namely to increase the development of science in the department of sociology especially those related to economic sociology and industrial sociology.

2. Practical uses, namely:

a) For high schools in Kupang city as input to pay attention to students in building solidarity.

b) For writers or researchers, this writing is knowledge that is an important contribution to the direct application of students to the theoretical knowledge gained during college. 


\section{The concept of Social Solidarity}

\section{THEORETICAL FRAMEWORK}

Solidarity is needed in social groups because every human being needs solidarity. The diversity of social groups will still exist if there is a sense of social solidarity. Social solidarity is a sense of mutual trust, solidarity, and a sense of continuity in every person as a group member because of the emotional and moral feelings shared.

\section{Forms of Social Solidarity}

Durkheim said that the development of a simple society towards modern society. One of the main things in the development of this society is a form of social solidarity that is a form of social solidarity of modern society and simple society is different. Durkheim's best-known opinion is the distinction between mechanical and organic solidarity. The following is a breakdown of the differences between a society with mechanical solidarity and a society with organic solidarity as follows:

Table 1.1. Society with mechanical solidarity and a society with organic solidarity (Johnson, 1986:188).

\begin{tabular}{|c|c|}
\hline Mechanical Solidarity & Organic Solidarity \\
\hline 1. Low division of labor & 1. High division of labor \\
\hline 2. Strong collective awareness & 2. Collective consciousness is weak \\
\hline 3. Dominant repressive law & 3. Dominant restitutive law \\
\hline $\begin{array}{l}\text { 4. Consensus on important normative } \\
\text { patterns }\end{array}$ & $\begin{array}{l}\text { 4. Consensus on important abstract and } \\
\text { general values }\end{array}$ \\
\hline 5. Low individuality & 5. High individuality \\
\hline $\begin{array}{l}\text { 6. Community involvement in punish those } \\
\text { who deviate }\end{array}$ & $\begin{array}{l}\text { 6. Social control bodies which punish deviant } \\
\text { persons }\end{array}$ \\
\hline 7. Relatively low interdependence & 7. High interdependence \\
\hline 8. Is primitive or rural & 8. Are urban industrial \\
\hline
\end{tabular}

\section{Social Interactions}

Social processes are related ways that are seen when individuals and social groups meet each other and determine the system and forms of the relationship or what will happen if there are changes that cause the shaky patterns of life that already exist. Social processes can be interpreted as a mutual influence between various aspects of shared life, for example influences between social and political, political and economic, economic and legal, etc. Social interaction is the key of all social life, because without social interaction there would be no life together.

Paul B. Horton said that people are a group of people who are relatively independent, who live together long enough, who inhabit a certain area, have the same culture and do most of the activities in the group. In another part Horton argues that society is a human organization that is interconnected with one another.

Soerjono Soekanto stated that the characteristics of a society in general are as follows.

Humans who live together, consisting of at least two people.

1. Mixed or hung out in a long time. Gathering of humans will lead to new human beings. As a result of living together, communication systems and regulations emerge that regulate human relations.

2. Aware that they are one entity.

3. Is a system of living together. The shared life system gives rise to culture because they feel themselves bound to one another. 


\section{School}

The school is a place of education for the nation's children. "Law Number 20 of 2003 concerning the National Education System, Article 3, the purpose of national education is to develop the potential of students to become human beings who believe and fear God Almighty, have noble, healthy, knowledgeable, capable, capable, creative, independent, and become democratic and responsible citizens. "

\section{Student}

Students are students or students who are the nation's next generation. In their daily lives in the school environment, of course there are always real social differences between students. Therefore students must have a solider personality in the form of empathy, mobility, participation to increase solidarity in social life at school.

Suyanto, (2005: 26). Social harmony and harmony and harmony are basically a mosaic composed of post-differences. Therefore, children who are educated from an early age to realize differences, undoubtedly what happens is not a conflict that manifests but rather what is present is tolerance in real life. School is a second environment for students who have a role in developing social solidarity so that they behave and act according to their nature as good social creatures.

\section{Types of research}

\section{RESEARCH METHODS}

According to Sugiyono (2009: 15), qualitative research methods are research used to investigate, discover, describe, and explain the quality or idiosyncrasy of social influence that cannot be explained, measured or illustrated through a quantitative approach. While Koentjoroningrat (1981: 42), what is meant by descriptive is a description as carefully as possible about an individual, condition, symptoms or certain groups. Based on the phenomena found in the field and preliminary observations which include collecting data describing the state of the object of research, therefore, the author tries to describe in full or intact the role of students in building solidarity among fellow students in their respective schools.

\section{Research sites}

This research was carried out in Kupang City 1 High School, Kupang City 21 High School, Kupang City 3 Public High School, Kupang City 4 Public High School, Kupang City 7 Public High School and Kupang City 8 High School .

\section{Research focus}

1. Analyzing the social solidarity of the mechanical high school students of the Kupang city state senior high school namely the togetherness and cooperation that exists with the students.

a. Determine the selection of friends and student participation in discussions or doing group assignments

b. Determine the system of division of tasks by students in working on group assignments

2. Describe the organic social solidarity of state high school students in Kupang city, namely:

a. Student social interaction (friendship between students)

b. Problems that exist in public high school students in the city of Kupang.

\section{Data Sources Primary Data}

Primary data sources in this study are: 
1. From 11 state high schools in Kupang city, six schools were represented representing 6 sub-districts in Kupang.

2. While the key informants are one hundred fifty (150) students, $10 \%$ of a total of three hundred and forty (340) class XI IPS students in Kupang City High School, determined through the sampling technique as follows:

Table 1.2. list of school names and respondents

\begin{tabular}{|c|l|c|c|}
\hline Num & School Name & Class / Amount & Total Students \\
\hline 1 & Kupang Public High School 1 & IX IPS/2 & 58 \\
\hline 2 & Kupang Public High School 2 & IX IPS/2 & 57 \\
\hline 3 & Kupang Public High School 3 & IX IPS/3 & 85 \\
\hline 4 & Kupang Public High School 4 & IX IPS/2 & 56 \\
\hline 5 & Kupang Public High School 7 & IX IPS/2 & 56 \\
\hline 6 & Kupang Public High School 8 & IX IPS/1 & 28 \\
\hline \multicolumn{3}{|c|}{ Total } & $\mathbf{3 4 0}$ \\
\hline
\end{tabular}

\section{Secondary Data}

Secondary data in this study were collected from literature searches or studies from various research archives, and documents and books on social solidarity studies.

\section{Data Collection Technique}

Field research (field work research), namely research activities carried out by dealing directly with the object under study in the field include:

1. Observation, namely direct observation in the field to find out and observe the state of life in SMA Negeri Kupang City to determine the objectivity of the student's situation.

2. In-depth interviews (indepth interview), namely researchers directly communication with students or informants in depth, intact and detailed to obtain complete, in-depth, and comprehensive information.

3. Documents, where the authors collect data by reading and taking all the documentation of events, events related to social solidarity problems in the City High School in the City of Kupang

\section{Data analysis technique}

After data collection, the next step is to reduce the data presented to draw conclusions or draw conclusions from the data presentation. If in the process of drawing conclusions an error occurs then returned to data collection.

\section{RESULTS AND DISCUSSION \\ Social Solidarity Among High School Students in Kupang City}

Social solidarity is "solidarity that refers to a state of relationship between individuals and / or groups based on moral feelings and shared beliefs reinforced by shared emotional experiences. The existence of social solidarity within a group will give birth to collective awareness within the group.

Paul Jonhson (1986: 181) is defined as a state of relationship between individuals and or groups based on moral feelings and shared beliefs reinforced by shared emotional experiences. In a society that adheres to mechanical solidarity, the priority is the equality of behavior and attitude. Differences are not justified. According to Durkheim, all citizens are bound by what is called collective awareness, collective conscience, a collective awareness that encompasses the whole beliefs and feelings of the group, and is external and coercive. Sanctions for violations of 
the law here are repressive; anyone who violates social solidarity will be subject to criminal penalties.

Whereas organic solidarity is a form of solidarity that binds a complex society of people who are familiar with the detailed division of labor and are united by interdependence between parts. In a society that adheres to mechanical solidarity, the priority is the equality of behavior and attitude. Differences are not justified. According to Durkheim, all citizens are bound by what is called collective awareness, collective conscience, a collective awareness that encompasses the whole beliefs and feelings of the group, and is external and coercive. Sanctions for violations of the law here are repressive; anyone who violates social solidarity will be subject to criminal penalties. This opinion shows that if students develop social solidarity in a group, there will be a harmonious atmosphere among the students so as to encourage the achievement of goals within the student group it self.

Relations between students have been fine because fellow students have the same goals at the beginning of entering the school environment. Solidarity in the members of the student group is so close because it is based on the basis of kinship and kinship, although there are many differences in residence, ethnicity, race and religion, but when entering school / registering there is no difference because each student has one goal.

The good and bad of student solidarity in Kupang State High Schools can be seen through one of the student activities namely through the division and participation of students in working on group assignments, namely:

1. The selection of friends is done by students in completing group assignments. In choosing friends to complete group assignments, sometimes the subject teacher determines it, but in general or more often students are only given the number of groups so that students are given the freedom to determine friends. This is where grouping occurs based on liking or liking or choosing friends who are deemed appropriate. This sometimes makes other friends uneasy because there is social jealousy. On the other hand if the teacher determines based on student absences then there is an equality that is even though it is suitable or not suitable, in line or not in line, but this group assignment system slowly begins to build a sense of responsibility in completing group assignments.

2. In the distribution of tasks when students work on group assignments that students themselves have the initiative that is the distribution of tasks tailored to student abilities. While student participation in discussing or doing group assignments varies, that is not all active because it is entrusted to students who are considered to have more knowledge than other students. However, although not all students participate, all students are actively involved or present in the discussion process until the presentation stage.

\section{Problems in Kupang High School students}

Problems that occur internally within students, usually caused by differences of opinion, differences of opinion or misunderstanding, but when there is a misunderstanding then fellow friends always encourage mutual forgiveness and if not resolved then the homeroom teacher or counseling guidance teacher calls and provides to provide understanding to reconcile. If it still continues, parents will be involved.

In the student environment, usually the problem that always occurs is that students are always at odds with other students and the nature of mastering and wanting to be appreciated is more emphasized. However, this problem has never been allowed to go on but it is resolved in a 
family manner based on a sense of shared fate and continuity. This is done in order to create a comfortable classroom or school environment. But in building a harmonious atmosphere, the students never miss to practice each other in every religious holiday. This is done by gathering together and visiting the home of every friend who celebrates the religious holiday. What is also interesting is that the classmates' birthday is always celebrated, it is also always used to make peace if there are unresolved previous problems, or if there is still an offense between students then this moment is considered the most appropriate to forgive each other.

\section{Mechanical Solidarity}

1. Family values as a value that is considered important for students are considered to be able to unite them as fellow students. Although it has not been internalized in general labor members. This condition is seen from the existence of minor conflicts among students in general.

2. Students blend and cooperate with each other in completing group assignments or group discussions, work done full of responsibility. this is what shows the close sense of togetherness of students.

\section{Organic Solidarity}

1. The division of groups has been determined based on the teacher or entrusted to students to determine friends in completing student group assignments. Impressed there is a business built for students to choose friends according to their wishes or preferences. This can cause inferiority and exclusion for other students. This is what teachers need to pay attention to so as not to give room for students to choose their friends to study in school.

2. If there is an error from the student then given advice and input from fellow students as well as the homeroom teacher and teacher counseling.

3. In general, students respect each other and feel responsible as a form of building togetherness. This can be seen from every group assignment, all present even though in working and presenting tasks and group discussions, there are only a few active.

4. Many differences in students such as ethnicity, religion, race, residence, social strata, economics. This is what makes the social solidarity of fellow students strong because it is based on the same sense of responsibility and purpose of students.

\section{Basic Factors of Social Solidarity Among Students}

The basic factors of social solidarity of Kupang State High School students are inseparable from the feeling of one ethnicity, the same ethnicity, originating from the same region, having the same interests and interests, a shared attachment to an educational institution, and so forth.

Students also have the same sense of being educated in a formal educational institution in the city of Kupang. In general, they come from various types of regions / cities or regencies and have different racial, ethnic, and religious differences. Values of sense of continuity, cooperation and solidarity between students can be a basis for a strong bond between students. Meanwhile, a sense of the same fate and continuity is used as a strong foundation for growth in the school environment among fellow students. This shows the meaning that is so thick in students that there is sympathy and empathy because it is based on caring for others and illustrates the importance of social solidarity itself that is the attitude possessed by humans that is the expression of human feelings because of a sense of unity and contempt for others , or group. If these values are maintained and are given more attention among students, they will greatly affect the life that is full of social solidarity for the next generation. 


\section{Conclusion}

\section{CONCLUSIONS AND SUGGESTIONS}

Social solidarity among the students of Kupang State High School is manifested through the similarity as students who study, feel a sense of responsibility in completing assignments. This can be seen from the collaboration developed through:

1. The division of tasks in completing group assignments, the role of each student,

2. Whereas the basic factors of solidarity among students are mutual help in completing group assignments, protecting each other if there is interference from outside the group, visiting each other during religious holidays and so forth. This is what builds a sense of solidarity or can accustom students to living in solidarity in their daily lives.

\section{Suggestions}

1. Kupang State High School students should always be accustomed to being aware of establishing intimacy among fellow students without seeing the differences between them or choosing friends as they wish.

2. The awareness of every student needs to get special attention, both from all teachers and the government or other related parties.

3. There needs to be a special program designed by schools or the government so that social solidarity can be improved. This is necessary because students are the next generation of the nation.

\section{References}

Johnson, Paul D. 1994. Teori Sosiologi: Klasik dan Modern, Jilid I dan II (Terj. Robert M.Z. Lawang). Gramedia : Jakarta

Koentjaraningrat. 1981. Metode Penelitian Masyarakat. LP3ES. Jakarta : LP3S

Soekanto, Soerjono. 1998. Sosiologi Suatu pengantar. Rajawali : Jakarta

Sugiyono. 2008. Metode Penelitian Kuantitatif, Kualitatif, dan R\&D. Bandung: Alfabeta.

Suyanto B. 2005. Metode Penelitian Sosial: Berbagai Alternatif Pendekatan. Jakarta: Prenada Media.

https://ainamulyana.blogspot.com/2018/06/undang-undang-uu-nomor-20-tahun-2003.html "Undang-Undang Nomor 20 tahun 2003 tentang Sistem Pendidikan Nasional.

https://www.quipper.com/id/blog/mapel/sosiologi/perubahan-sosial-menurut-para-ahli/ Perubahan Sosial Menurut Para Ahli 